\title{
Effects of Human Chorionic Gonadotropin on the Testis of Adult Albino Rats \\ A Histological and Histochemical Study
}

Waleed H. Kasim, Maha A. Al-Sammak

University of Ninevah, College of Medicine, Department of Anatomy

\section{$\underline{\text { Received }}$ Accepted \\ 25.5.2014 11.3.2018}

\begin{abstract}
Aims of the study: To evaluate the histopathological changes induced by human chorionic gonadotropin (hCG) on the adult testis and to correlate the changes with the levels of testosterone, $\mathrm{LH}$ and $\mathrm{FSH}$, as well as to assess their reversibility.

Methods: 80 adult male albino rats were divided into 4 groups; 3 treated and 1 control. The treated groups were received 10,50 or $100 \mathrm{IU} / \mathrm{kg} \mathrm{BW}$ of $\mathrm{hCG}$, while the controls received normal saline. The doses were given twice weekly for 3 months via S.C. injections. Subsequently, on day 1, 30, 60 and 90 post therapy, blood samples and the testes were obtained for evaluation.

Results: Low dose of hCG caused increase in number of germ and Sertoli cells. Contrary, higher doses decreased their population, and resulted in exfoliation of the germ cells. Furthermore, reduction in the thickness of the tubular basement membrane, congestion of the inter-tubular blood vessels and interstitial bleeding were observed in the higher dose groups. All the doses caused interstitial oedema, hyperplasia and hypertrophy of Leydig cells, as well as diminution in the collagen fibers. All these changes were reversible within 3 months.
\end{abstract}

Conclusions: Only the low doses of hCG stimulate the spermatogenesis, whereas higher doses suppress sperm production.

Keywords: histopathological; spermatogenesis; exfoliation; reversibility.

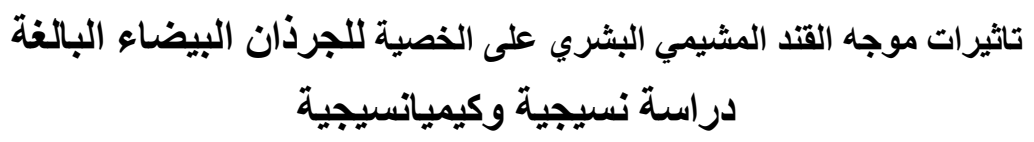

الخلاصة

الهدف: تم تصميم هذه الدر اسة لغرض تحديد التغيرات النسيجية المرضية الناجمة عن استخدام موجه القند المشيمي

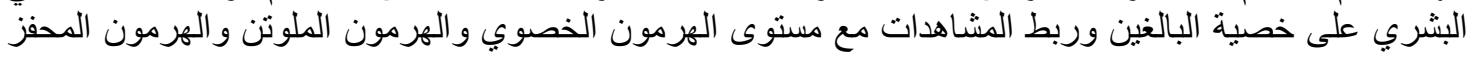
للجريب، وكذللك التقيبم قابلية عكوسيتها.

طرق العمل: تم تقسيم 80 من ذكور الجرذان البيضاء البالغة إلى 4 مجموعات؛ 3 للمعالجة وواحدة للسيطرة.

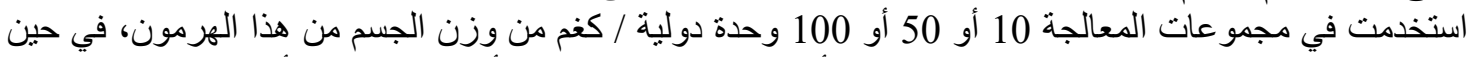
استخدم محلول ملحي عياري لمجموعة المقايسة. أعطيت الجرعات مرتين أسبو عبا لمدة 3 أشهر عن طريق الهرن الحقن 


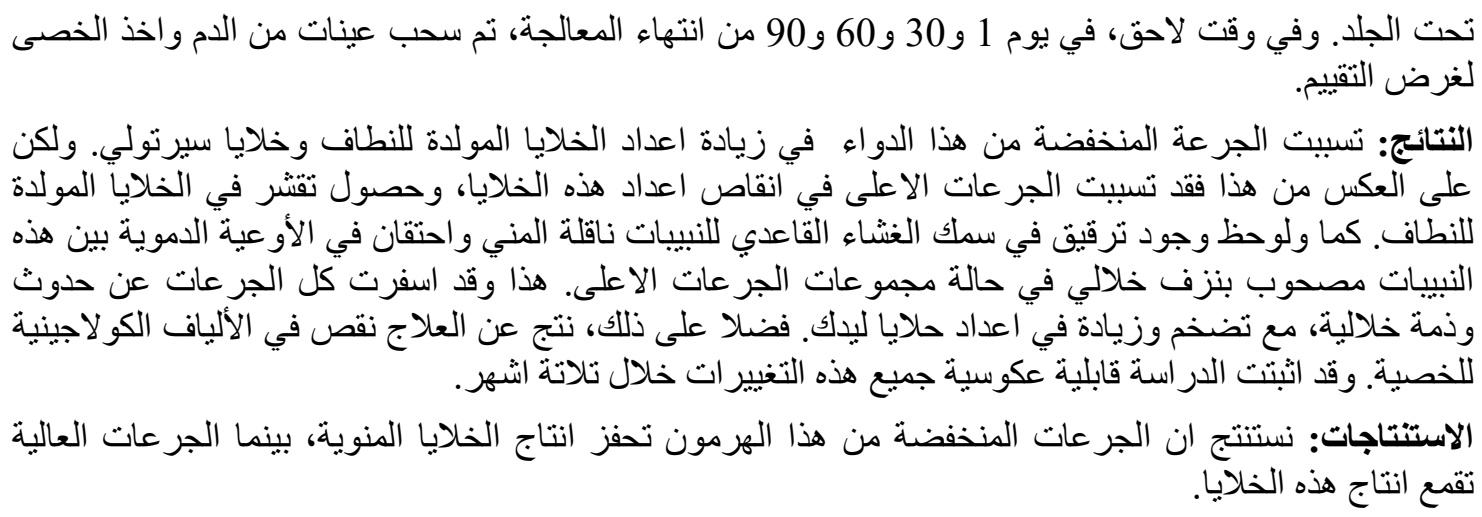

$\mathrm{H}$

uman chorionic gonadotropin (hCG) is a placental glycoprotein hormone with pharmacological actions virtually identical to those of $\mathrm{LH}^{1}$. This hormone can be extracted from the urine of pregnant females and its preparations are widely used as therapeutic agents by both sexes. In males, its administration is accompanied by an increase in libido, improvement of sexual performance and elevation of sperm count ${ }^{2}$. Whereas, in females hCG administration is associated with a favorable outcome during ovarian stimulation, since higher pregnancy rates occurred in cycles in which hCG was given ${ }^{3}$.

In addition to its many therapeutic uses, this hormone is frequently abused by many people across the ward unaware of the hidden side effects associated with it. With the recent introduction of several newer commercial forms of hCG, there is an escalating abuse of this drug. Besides the injectable form, hCG products are available as sublingual drops, lozenges, and pellets, but none of these forms has an evidence-based efficacy and safety standard ${ }^{4}$. Furthermore, these forms are simple and easy to administer by the abusers without any pain. Authors demonstrated that the use of hCG preparations is associated with many side effects.
Though, data concerning the histopathological effects on the testis are very deficient.

\section{Aims of the study}

This experimental study was designed to evaluate the histopathological, histochemical, and morphometrical effects of different therapeutic doses of hCG on the testis of adult albino rats, and to assess the reversibility of the changes at one month intervals from cessation of the therapy for another three months. Serum levels of testosterone, LH and FSH were verified to correlate the induced changes with the hormone values.

\section{Materials and methods}

\section{Animals and housing}

Eighty healthy adult male albino rats of Wistar strain were housed in polypropylene cages $(55 \times 37 \times 15 \mathrm{~cm})$ with stainless steel top grill, in groups of ten rats per cage, for the period from January till the end of June 2013. A number of female rats were reserved with them to maintain their normal sexual activities. The animals were maintained in a well ventilated, air conditioned room under natural conditions of approximately 12 hours light and dark cycle, and a temperature 
of about $25 \pm 2^{\circ} \mathrm{C}$. During the whole period, the animals had access to tap water and were fed with commercially prepared food ad libitum.

\section{Drug and administration}

Human chorionic gonadotropin (Pregnyl®) ampoules were purchased from Organon, the Netherlands. Each ampoule contains 500 IU freeze-dried powder of hCG. The powder was reconstituted with $30 \mathrm{cc}$ normal saline to obtain suitable concentration of the drug. Doses were administered via subcutaneous injections into the dorsal aspect of the rats, between the shoulder blades, by mean of disposable U-100 insulin syringes.

\section{Experimental protocol}

The rats were divided randomly into 4 groups of 20 animals each; 3 treated groups A, B, and C, while Group D was served as a control. The treated groups were received 10,50 or $100 \mathrm{IU} / \mathrm{kg} \mathrm{BW}$ of hCG respectively, whereas the control group received equal amounts of normal saline. The injections were administered to the animals twice weekly for 3 months (total 24 doses). Subsequently, on day 1, 30, 60 and 90 post therapy, 5 rats from each group were anesthetized, blood samples were collected for hormonal assay, and finally the animals were euthanized and sacrificed to obtain the testes for evaluation.

\section{Blood samples collection}

The animals were anesthetized by low dose of diethyl ether, after that a needle was inserted through the intercostal space on the left side at the point of maximum intensity of the heart beat, and blood samples were aspirated. The samples were allowed to clot in plain containers and kept in refrigerator.

\section{Euthanasia and necropsy}

The rats were euthanized by inhalation of an intensive dose of diethyl ether in a Glass desiccator. This practice was performed in accordance with the American Veterinary Medical Association (AVMA) guidelines for the euthanasia of animals (2013). A scissor was used to make a mid ventral incision through the abdomen extending into the scrotal sac to obtain the testes.

\section{Fixation, staining and histological examination}

The testes were fixed in Bouin's solution. Sequentially, the processed sections were stained with Hematoxylin and Eosin (H\&E), Periodic acid-Schiff (PAS) and Van-Gieson's (VG). The stained sections of the control and the treated groups were studied thoroughly under light microscope (Olympus, Tokyo, Japan). And they were analyzed quantitatively using visopan projection microscope (Reichert, Austria).

\section{Hormonal assay}

Serum testosterone, LH, and FSH levels were determined using luminescence technology in combination with magnetic micro particles (LIAISON). All hormone assays were run in the same laboratory to eliminate any difference in the results. The values of the control group were considered as standard, and they were compared with the results obtained from the different treated groups.

\section{Statistical analysis}

Numerical data obtained from each group were expressed as mean \pm standard deviation (SD). Statistical significance of the data was determined using Student's $t$ test. Comparisons of data from different groups were evaluated by ANOVA. P values less than 0.05 were considered statistically significant. 


\section{Results}

\section{Hormones}

Human chorionic gonadotropin therapy resulted in a marked elevation of the serum testosterone, with suppression of both LH and FSH levels. The alteration of the hormone levels was dose dependent. On the other hand, the magnitude of the effects of hCG appear to be dose limited; all data showed no any statistically significant difference between those received 50 or $100 \mathrm{IU} / \mathrm{kg}$ BW. Although, all the hormone levels were affected by the therapy, but an extraordinary degree of reduction was detected in FSH levels, which were declined to a very low and undetectable levels in groups $\mathrm{B}$ and $\mathrm{C}$.

Successive evaluation of serum hormone levels manifested sensible and continuous improvement of their values. By the end of first month post therapy, FSH levels showed non significant difference in their values as compared with the normal, while testosterone and LH levels demonstrated variable degrees of recovery at this time. Ultimately, by the end of second month post therapy, the values of testosterone and LH were also analogous to those of the normal (table 1).

\section{Microscopical Observations}

The parameters of the seminiferous tubules and Leydig cells are presented in tables $2,3 \& 4$.

The different doses of hCG resulted in various multifocal histological changes in the seminiferous tubules and interstitial tissues. Though, the mean seminiferous tubule diameter was not affected by the therapy. All testis sections of group A revealed hypercellularity of the germinal epithelium and dramatic diminution of the tubular lumen (figure 1). Contrary,
Approximately $80 \%$ of the seminiferous tubule sections of groups $\mathrm{B}$ and $\mathrm{C}$ revealed poor differentiation of the germinal epithelium, exfoliation of the spermatogenic cells, with presence of acidophilic material or debris in their lumens (figure 2). Several segments of their tubules were lined with Sertoli cells and spermato-gonia only. Moreover, the therapy caused reduction in the thickness of the basement membrane of all the treated groups, though it was not significant in group A.

The interstitial spaces of the different dose groups were widened and demonstrated many foci of interstitial oedema. Additionally, frequent dilated and congested inter-tubular blood vessels, ruptured blood capillaries with extra-vasation of RBCs were noticed in the higher dose groups. The therapy also resulted in a dose dependent hyperplasia and non dose dependent hypertrophy of Leydig cells. Morphometric data indicated that the effect of hCG was dose limited, since no significant differences were reported between groups B and C. On the other hand, the histochemical study revealed no alteration in general distribution of the PAS +ve material of the testis (figure 3 ). Whereas, The VG stained sections showed reduction in collagen fiber content of the seminiferous tubule lamina propria and the interstitial stroma (figure 4).

The follow up period revealed gradual recovery of the testes of all treated groups. By the end of the second month following the therapy, the vast majority of the seminiferous tubule sections and the interstitial spaces restored their normal histological appearance. Similarly, the morphometric data obtained at this period of time regarding the parameters of seminiferous 
tubules, values of spermatogenic and Sertoli cells, as well as the values of Leydig cells, showed no significant difference as compared with the controls. In addition, the recovery of the collagen fibers of the tubular lamina propria and the interstitial stroma ensued by the end of the third month after cessation of the therapy.

Table 1: Values of serum hormones level

\begin{tabular}{|c|c|c|c|c|}
\hline \multirow{3}{*}{ Group } & Period & $\begin{array}{c}\text { Testosterone } \\
(\mathbf{n g} / \mathbf{m l})\end{array}$ & $\begin{array}{c}\text { LH } \\
(\mathbf{m I U} / \mathbf{m l})\end{array}$ & $\begin{array}{c}\text { FSH } \\
(\mathbf{m I U} / \mathbf{m l})\end{array}$ \\
\hline \multirow{4}{*}{ Control } & All periods & $1.95 \pm 0.18$ & $0.94 \pm 0.03$ & $1.52 \pm 0.19$ \\
\hline \multirow{4}{*}{ A } & Day 1 & $3.49 \pm 0.10^{*}$ & $0.59 \pm 0.11^{*}$ & $0.44 \pm 0.09^{*}$ \\
\cline { 2 - 5 } & Day 30 & $3.38 \pm 0.93^{*}$ & $0.78 \pm 0.16^{*}$ & $1.38 \pm 0.22$ \\
\cline { 2 - 5 } & Day 60 & $1.99 \pm 0.04$ & $0.88 \pm 0.03$ & $1.49 \pm 0.16$ \\
\hline \multirow{4}{*}{ B } & Day 90 & $1.97 \pm 0.14$ & $0.92 \pm 0.01$ & $1.51 \pm 0.22$ \\
\cline { 2 - 5 } & Day 1 & $4.84 \pm 0.26^{*}$ & $0.40 \pm 0.07^{*}$ & $<0.25^{*}$ \\
\cline { 2 - 5 } & Day 30 & $4.31 \pm 0.72^{*}$ & $0.58 \pm 0.08^{*}$ & $1.33 \pm 0.18$ \\
\cline { 2 - 5 } & Day 60 & $2.05 \pm 0.12$ & $0.85 \pm 0.04$ & $1.43 \pm 0.05$ \\
\hline \multirow{4}{*}{ C } & Day 90 & $2.16 \pm 0.40$ & $0.91 \pm 0.03$ & $1.46 \pm 0.09$ \\
\cline { 2 - 5 } & Day 1 & $5.19 \pm 0.45^{*}$ & $0.40 \pm 0.10^{*}$ & $<0.25^{*}$ \\
\cline { 2 - 5 } & Day 30 & $3.93 \pm 0.16^{*}$ & $0.57 \pm 0.09^{*}$ & $1.35 \pm 0.17$ \\
\cline { 2 - 5 } & Day 60 & $2.09 \pm 0.19$ & $0.86 \pm 0.03$ & $1.41 \pm 0.08$ \\
\hline & Day 90 & $2.01 \pm 0.16$ & $0.90 \pm 0.01$ & $1.5 \pm 0.19$ \\
\hline
\end{tabular}

Data are expressed as mean $\pm \mathrm{SD}$

${ }^{*}$ Values of significant difference at $p<0.001$ 
Table 2: Parameters of the seminiferous tubules $(\mu \mathrm{m})$

\begin{tabular}{|c|c|c|c|c|c|}
\hline \multirow{3}{*}{ Group } & Period & $\begin{array}{c}\text { Tubular } \\
\text { diameter }\end{array}$ & $\begin{array}{c}\text { Luminal } \\
\text { diameter }\end{array}$ & $\begin{array}{c}\text { Germinal } \\
\text { epithelium } \\
\text { thickness }\end{array}$ & $\begin{array}{c}\text { Basement } \\
\text { membrane } \\
\text { thickness }\end{array}$ \\
\hline \multirow{3}{*}{ Control } & All periods & $328.9 \pm 20.42$ & $135.5 \pm 9.85$ & $94.8 \pm 16.74$ & $7.9 \pm 0.87$ \\
\hline \multirow{4}{*}{ A } & Day 1 & $329.8 \pm 18.53$ & $82.3 \pm 21.14^{*}$ & $124.3 \pm 19.34^{*}$ & $7.2 \pm 0.81$ \\
\cline { 2 - 6 } & Day 30 & $332.3 \pm 21.03$ & $93.5 \pm 14.56^{* *}$ & $120.6 \pm 17.92^{*}$ & $7.5 \pm 0.96$ \\
\cline { 2 - 6 } & Day 60 & $328.4 \pm 24.27$ & $124.7 \pm 20.76$ & $98.6 \pm 20.64$ & $7.6 \pm 0.93$ \\
\cline { 2 - 6 } & Day 90 & $326.4 \pm 22.36$ & $131.4 \pm 18.97$ & $97.3 \pm 21.66$ & $7.8 \pm 0.85$ \\
\hline \multirow{4}{*}{ B } & Day 1 & $327.1 \pm 16.65$ & $175.4 \pm 25.63^{*}$ & $71.9 \pm 18.31^{*}$ & $4.3 \pm 0.15^{*}$ \\
\cline { 2 - 6 } & Day 30 & $325.9 \pm 13.74$ & $157.6 \pm 20.75^{* *}$ & $83.4 \pm 17.12^{*}$ & $5.7 \pm 0.91^{*}$ \\
\cline { 2 - 6 } & Day 60 & $333.4 \pm 14.47$ & $143.2 \pm 17.97$ & $94.7 \pm 15.30$ & $7.5 \pm 0.84$ \\
\cline { 2 - 6 } & Day 90 & $324.6 \pm 12.56$ & $135.1 \pm 20.36$ & $95.1 \pm 16.61$ & $7.8 \pm 0.90$ \\
\hline \multirow{3}{*}{ C } & Day 1 & $331.2 \pm 29.94$ & $173.3 \pm 22.02^{*}$ & $74.2 \pm 19.20^{*}$ & $4.6 \pm 0.97^{*}$ \\
\cline { 2 - 6 } & Day 30 & $329.4 \pm 17.09$ & $152.1 \pm 18.84^{* *}$ & $85.3 \pm 19.49^{*}$ & $5.4 \pm 0.70^{*}$ \\
\cline { 2 - 6 } & Day 60 & $327.7 \pm 19.15$ & $140.5 \pm 12.87$ & $94.1 \pm 11.62$ & $7.4 \pm 0.86$ \\
\cline { 2 - 6 } & Day 90 & $330.2 \pm 24.08$ & $133.4 \pm 10.44$ & $96.6 \pm 20.53$ & $7.9 \pm 0.86$ \\
\hline
\end{tabular}

Data are expressed as mean $\pm \mathrm{SD}$

*Values of significant difference at $p<0.005$

** Values of significant difference at $p<0.05$

Table 3: Values of the spermatogenic and Sertoli cells

\begin{tabular}{|c|c|c|c|c|c|}
\hline \multirow{3}{*}{ Group } & Period & Spermatogonia & Spermatocytes & Spermatids & Sertoli cells \\
\hline \multirow{4}{*}{ Control } & All periods & $38.8 \pm 8.43$ & $102.6 \pm 11.63$ & $168.4 \pm 17.53$ & $15.1 \pm 4.2$ \\
\hline \multirow{4}{*}{ A } & Day 1 & $49.6 \pm 14.91^{*}$ & $121 \pm 16.60^{*}$ & $197.4 \pm 17.31^{*}$ & $21.6 \pm 6.69^{*}$ \\
\cline { 2 - 6 } & Day 30 & $46.2 \pm 11.51^{*}$ & $114.6 \pm 20.72^{*}$ & $182.2 \pm 12.22^{*}$ & $18.80 \pm 2.38^{*}$ \\
\cline { 2 - 6 } & Day 60 & $40.6 \pm 10.11$ & $106.6 \pm 8.09$ & $171.4 \pm 17.83$ & $15.6 \pm 2.59$ \\
\cline { 2 - 6 } & Day 90 & $39.6 \pm 4.89$ & $101.1 \pm 14.20$ & $172.1 \pm 11.44$ & $15.5 \pm 4.35$ \\
\hline \multirow{4}{*}{ B } & Day 1 & $25.8 \pm 7.12^{*}$ & $61.3 \pm 12.67^{*}$ & $96.8 \pm 11.80^{*}$ & $8.7 \pm 2.56^{*}$ \\
\cline { 2 - 6 } & Day 30 & $33.9 \pm 10.44^{*}$ & $81.6 \pm 13.58^{*}$ & $116.7 \pm 15.90^{*}$ & $12.8 \pm 3.55^{*}$ \\
\cline { 2 - 6 } & Day 60 & $37.7 \pm 4.29$ & $95.6 \pm 13.78$ & $157.8 \pm 11.09$ & $14.3 \pm 4.93$ \\
\cline { 2 - 6 } & Day 90 & $36.9 \pm 7.25$ & $104.7 \pm 10.09$ & $174.2 \pm 21.33$ & $14.7 \pm 5.19$ \\
\hline \multirow{4}{*}{ C } & Day 1 & $27.9 \pm 9.84^{*}$ & $59.9 \pm 16.34^{*}$ & $94.1 \pm 17.11^{*}$ & $8.3 \pm 4.38^{*}$ \\
\cline { 2 - 6 } & Day 30 & $36.1 \pm 8.57^{*}$ & $78.5 \pm 9.11^{*}$ & $122.5 \pm 21.40^{*}$ & $12.4 \pm 5.10^{*}$ \\
\cline { 2 - 6 } & Day 60 & $37.2 \pm 8.33$ & $98 \pm 9.10$ & $160.1 \pm 20.29$ & $13.6 \pm 4.10$ \\
\cline { 2 - 6 } & Day 90 & $38.6 \pm 7.54$ & $102.8 \pm 12.85$ & $169.5 \pm 20.66$ & $15.8 \pm 5.76$ \\
\hline
\end{tabular}

Data are expressed as mean value/seminiferous tubule cross section \pm SD

* Values of significant difference at $p<0.05$ 
Table 4: Parameters of Leydig cells

\begin{tabular}{|c|c|c|c|}
\hline \multirow{3}{*}{ Group } & Period & $\begin{array}{c}\text { Number of Leydig cells / } \\
\text { interstitial space }\end{array}$ & $\begin{array}{c}\text { Diameter of Leydig cells } \\
(\boldsymbol{\mu m})\end{array}$ \\
\hline \multirow{3}{*}{ Control } & All periods & $14.3 \pm 2.27$ & $5.8 \pm 0.93$ \\
\hline \multirow{4}{*}{ A } & Day 1 & $21.6 \pm 2.56^{*}$ & $7.2 \pm 0.53^{*}$ \\
\cline { 2 - 4 } & Day 30 & $20.1 \pm 1.86^{*}$ & $6.8 \pm 0.76^{*}$ \\
\cline { 2 - 4 } & Day 60 & $15.2 \pm 3.67$ & $5.9 \pm 1.10$ \\
\cline { 2 - 4 } & Day 90 & $14.5 \pm 5.39$ & $5.9 \pm 0.64$ \\
\hline \multirow{4}{*}{ B } & Day 1 & $30.8 \pm 3.70^{*}$ & $7.3 \pm 0.43^{*}$ \\
\cline { 2 - 4 } & Day 30 & $23.7 \pm 3.42^{*}$ & $6.7 \pm 0.88^{*}$ \\
\cline { 2 - 4 } & Day 60 & $16.1 \pm 6.72$ & $6.1 \pm 0.73$ \\
\cline { 2 - 4 } & Day 90 & $15.2 \pm 7.47$ & $6 \pm 0.90$ \\
\hline \multirow{4}{*}{ C } & Day 1 & $31.4 \pm 3.87^{*}$ & $7.1 \pm 0.79^{*}$ \\
\cline { 2 - 4 } & Day 30 & $24.2 \pm 3.90^{*}$ & $6.9 \pm 0.53^{*}$ \\
\cline { 2 - 4 } & Day 60 & $16 \pm 8.80$ & $6.2 \pm 0.38$ \\
\cline { 2 - 4 } & Day 90 & $14.9 \pm 9.34$ & $6 \pm 0.49$ \\
\hline
\end{tabular}

Data are expressed as mean \pm SD

${ }^{*}$ Values of significant difference at $p<0.005$

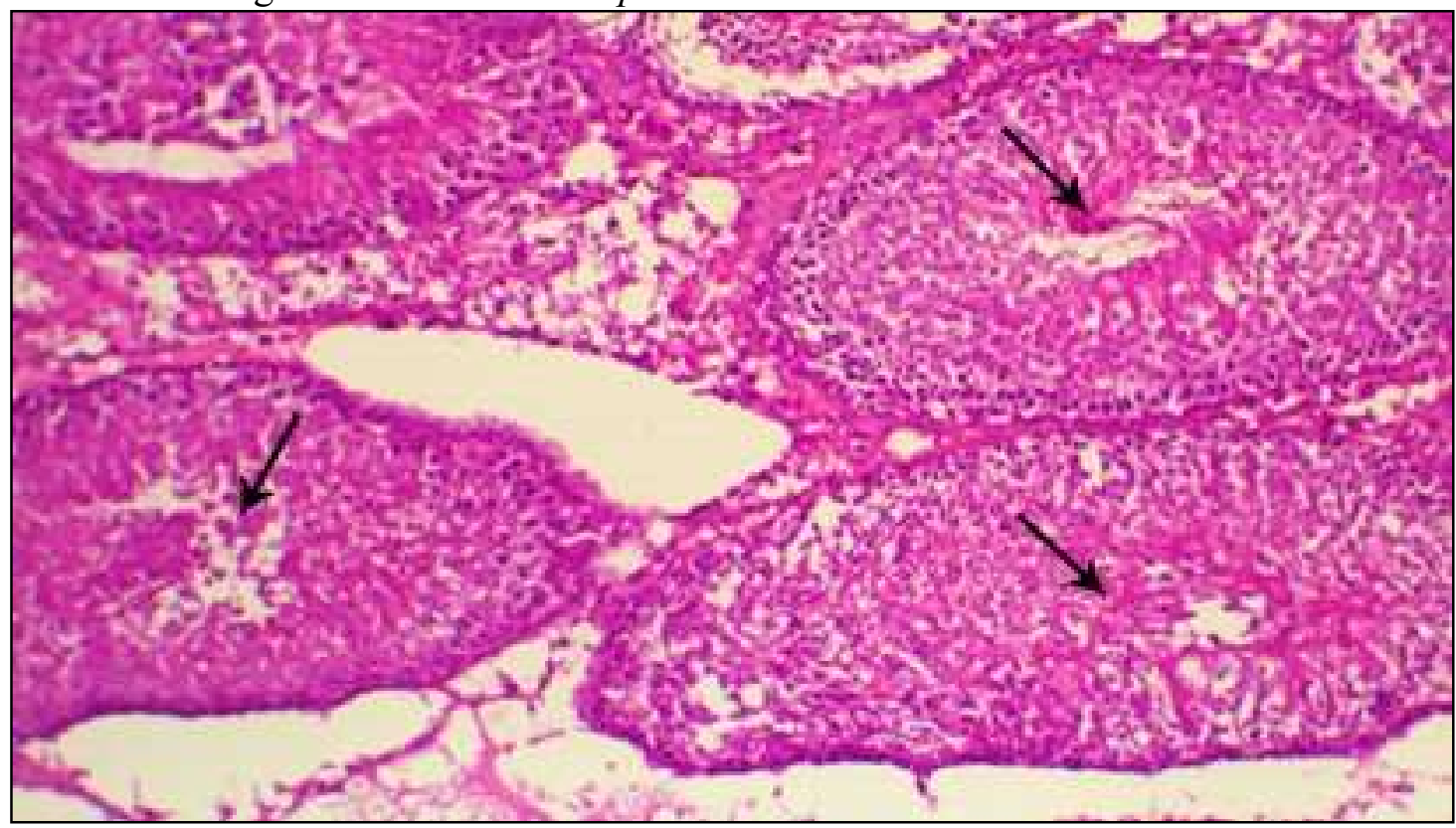

Figure 1: A photomicrograph of a section in the testis of a rat from group A, on day 1 post treatment, showing seminiferous tubules with hypercellularity and narrow lumen (arrows), (H\&Ex100). 


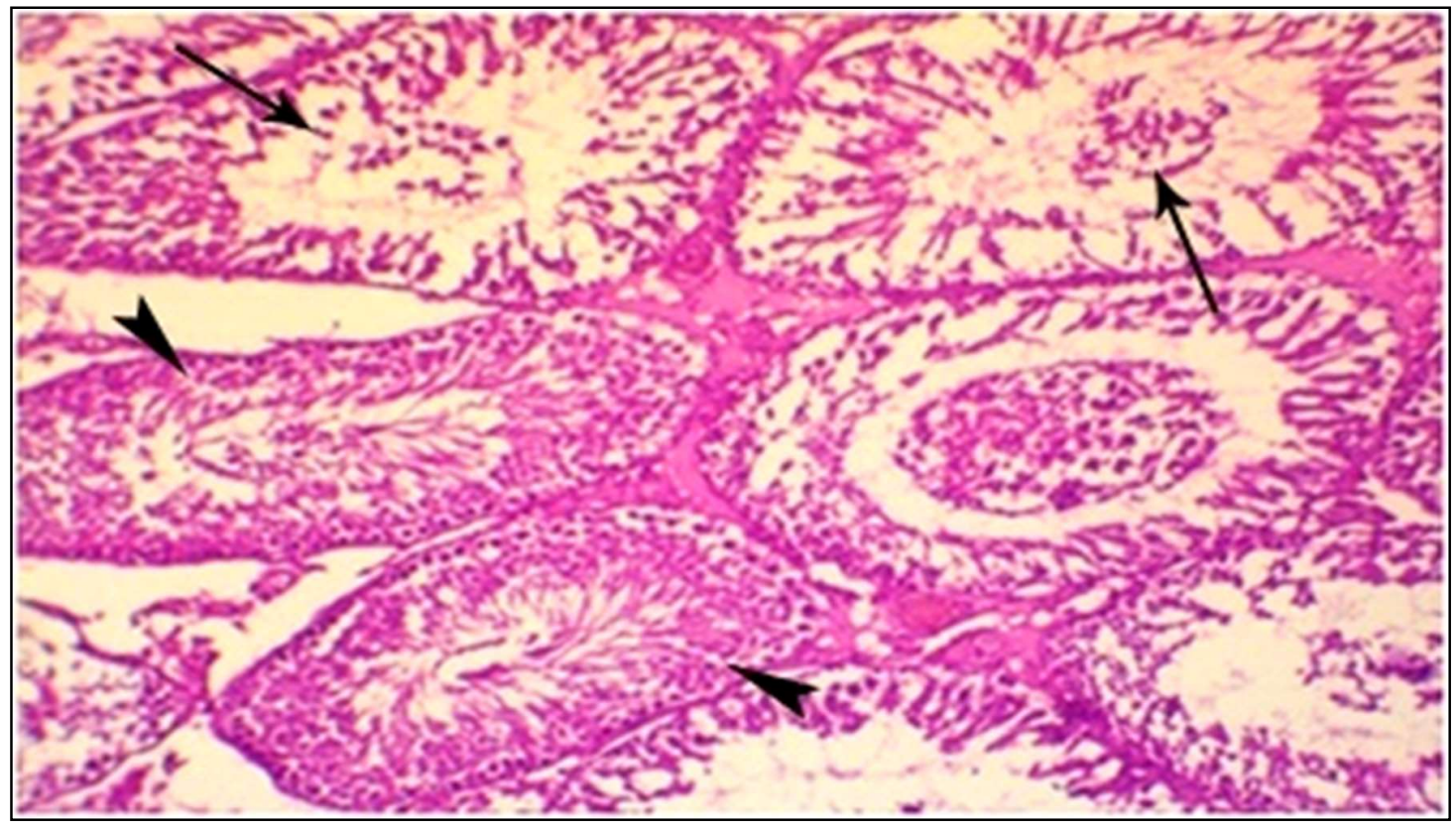

Figure 2: A photomicrograph of a section in the testis of a rat from group B, on day 1 post treatment, showing seminiferous tubules with hypocellularity, exfoliation of the germ cells, and cell debris (arrows), others with normal cellularity (arrowheads), (H\&E x 100).

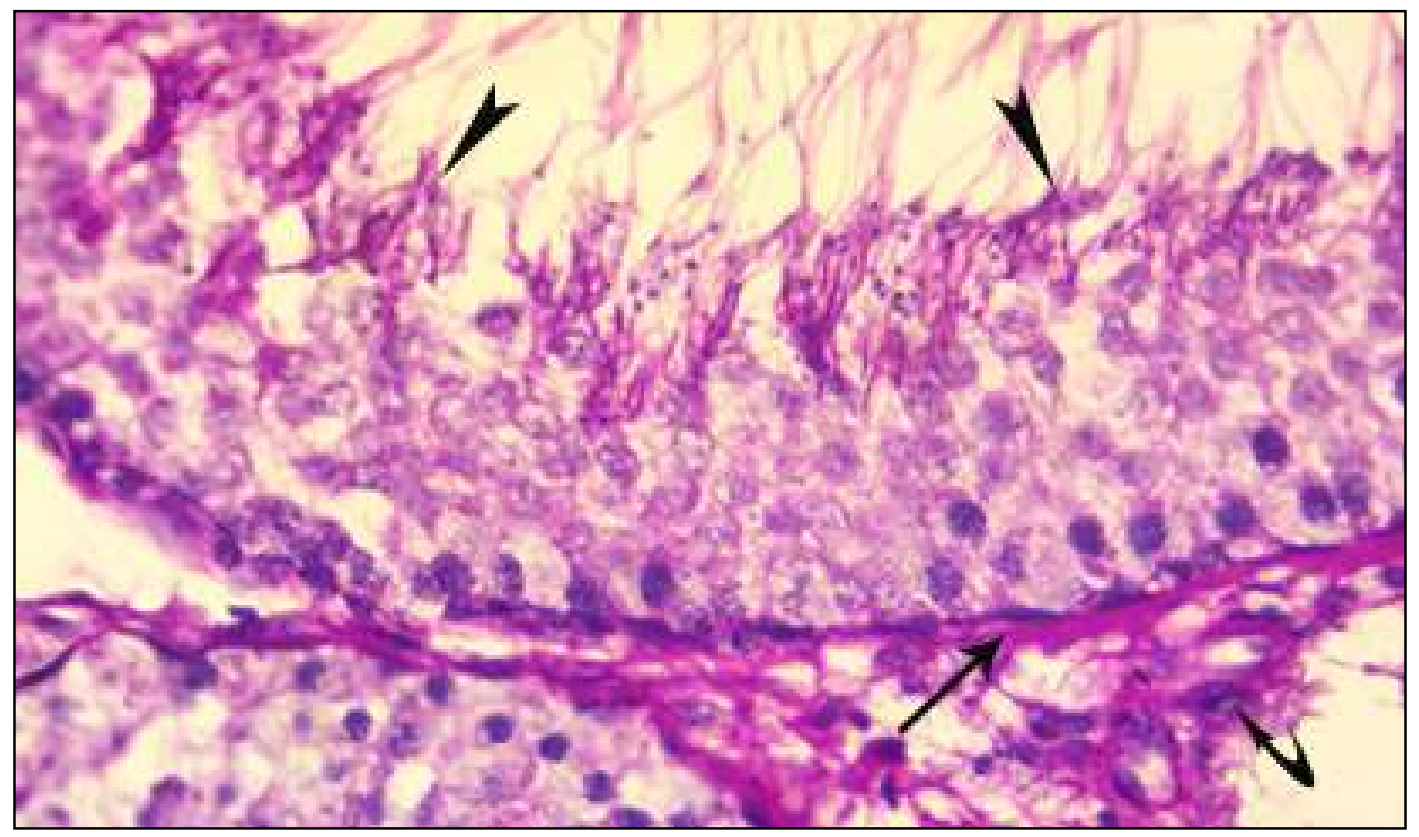

Figure 3: A photomicrograph of a section in the testis of a control rat, showing intense PAS reaction in the basement membrane (arrow), spermatids (arrowheads), and Leydig cells (curved arrow), (PAS x400). 


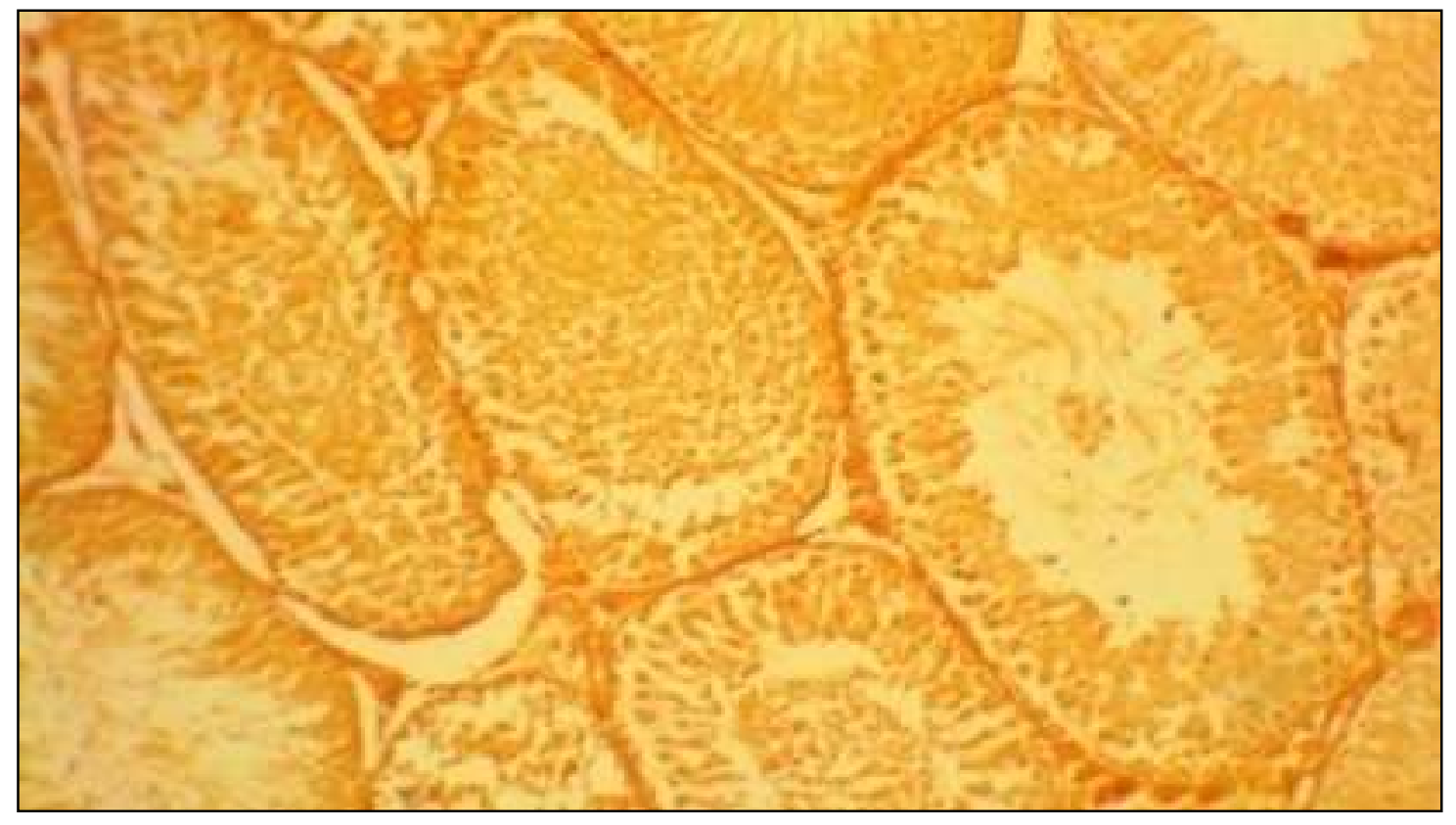

Figure 4: A photomicrograph of a section in the testis of a rat from group A, on day 1 post treatment showing decrease in the collagen fiber content (VG $\times 100)$.

\section{Discussion}

Studies confirmed that both FSH and LH act on the testis to regulate spermatogenic potential. LH binds to receptors on the surface of Leydig cells and stimulates the production of testosterone, which diffuses into the seminiferous tubules. Within the seminiferous tubules only Sertoli cells possess receptors for testosterone and $\mathrm{FSH}$, thus these cells are the major targets of the ultimate hormonal signals that regulate spermatogenesis ${ }^{5}$.

Testosterone is obligatory for spermatogenesis, while FSH plays a valuable role in this process ${ }^{6}$. Several researches have been performed to evaluate the relative role of FSH in restoration of normal spermatogenesis. Studies on human and mice affirmed that FSH is not essential for spermatogenesis but is required for quantitatively normal sperm production ${ }^{7}$ Conversely, Monkeys with long term immunization against FSH developed oligospermia or azoospermia, in case of oligospermia the few sperms left were probably functionally impaired, as these monkeys were infertile. Similar findings have been detected in human volunteers receiving vaccine against $\mathrm{FSH}$; they revealed alteration in the parameters of sperm quality ${ }^{8}$. Data from mice lacking FSH revealed reduction in sperm count and motility, however all stages of spermatogenesis were identified among some of the tubules of these mice ${ }^{9}$. Indicating that elimination of FSH not only causes quantitatively, but also qualitatively damage of spermatogenesis.

Takashi et al. (2007) ${ }^{10}$ stated that FSH promotes the secretion of various growth factors by Sertoli cells that then stimulate spermatogenesis. William and Jing $(2005)^{5}$ established that binding of FSH to its receptor activates at least five signaling pathways in Sertoli cells which 
promote sperm production. Moreover, Dama and Singh (2009) ${ }^{11}$ explained the effect of FSH on spermatogenesis via formation of Androgen-Binding Protein (ABP) by the Sertoli cells, this protein is required to maintain high local concentration of androgens in the seminiferous tubules. Thus, the suppression of FSH level reduces the intratesticular testosterone.

According to these studies and in agreement with Da-Nian and Mary $(2000)^{12}$ both FSH and testosterone are involved as synergistic in the process of spermatogenesis. The results of this experimental study might explain the declaration of Slowikowska and Kula $(1994)^{13}$ who stated that only the lowest doses of hCG stimulate the spermatogenesis, while higher doses suppress it. Rats of group A manifested an elevated serum level of testosterone, but at the same time their serum level of FSH was lower than that of the normal. However, the synergistic activity of this FSH level with the high testosterone level achieved by the hCG therapy appeared to be sufficient to enhance spermatogenesis, which was manifested as hypercellularity of the seminiferous tubules with narrowing if their lumens. In contrast, rats of groups $\mathrm{B}$ and $\mathrm{C}$ showed higher testosterone levels, nevertheless their serum FSH dropped to undetectable levels, so they demonstrated lessening in number of the spermatogenic cells with widening of the seminiferous tubule lumen. However, no complete germ cell loss was detected in these groups, probably due to the synergistic action of the small FSH-like activity of hCG which has been described by Kitanaka et al. (1994) ${ }^{14}$. Although, Ihsan et al. (2006) ${ }^{15}$; Kaya et al. $(2006)^{16}$ reported cases of Sertoli cell only appearance in rats received 50 IU of hCG once daily for 15 days.

It is generally accepted that Sertoli cells provide critical factors necessary for the successful progression of spermatogonia into spermatozoa. Previous authors have been believed that Sertoli cells stopped proliferating at puberty and became terminally differentiated quiescent cells. However, recent study by Meachem et al. (2007) ${ }^{17}$ showed that adult Sertoli cells can retain their proliferative ability and they are capable to re-acquire features reminiscent of immature Sertoli cells. Furthermore, Sofikitis et al. (2005) ${ }^{18}$ stated that Sertoli cells limit the expansion of the spermatogonial population, with each Sertoli cell supporting a defined number of germ cells. Accordingly, the increase in the number of spermatogenic cells was accompanied with proliferation of Sertoli cells, which took place probably due to the mitotic activity of FSH on Sertoli cells which has been stated by Charles et al. (2003) ${ }^{19}$. Contrary, the acute FSH suppression in groups B and $\mathrm{C}$ immediately after the hCG resulted in reduction in the number of Sertoli cells, as affirmed by Sarah et al. (2005) ${ }^{20}$.

William and Jing (2010) ${ }^{21}$ reported that spermatocytes and round spermatids are connected to Sertoli cells via desmosomes that use intermediate filaments as their attachment sites. Lynda et al. $(2002)^{22}$ established that disturbance of these intercellular junctions leads to loss of germ cell adherence to Sertoli cell and this will result in exfoliation of the germ cells. Moreover, O'Donnell et al. (2000) ${ }^{23}$ concluded that these junctional complexes are likely dependent on intratesticular testosterone concentration. 
Accordingly, the suggested suppression of intratesticular testosterone concentration due to the extremely low FSH serum levels achieved in groups $\mathrm{B}$ and $\mathrm{C}$ resulted in exfoliation of the germ cells into the lumen of the seminiferous tubules.

The observation of seminiferous tubule segments lined with Sertoli cells and spermatogonia only in this study is consistent with that of Kerr and Sharpe (1989) ${ }^{24}$ who noticed foci of seminiferous tubules with partial loss of spermatogonia and primary spermatocytes associated with hCG therapy. They stated that following stimulation of the Leydig cells by hCG, the inter-tubular tissue exhibits an inflammatory-type response and this is associated with focal tissue destruction in the seminiferous tubules. However, this damage is temporary and appears to be reversible, which is in agreement with Hjertkvist et al. (1993) ${ }^{25}$ who noticed no tubular damage in the testis of cryptorchid boy studied 6-12 months after the last hCG injection.

In accordance with Stina et al. $(2004)^{26}$ hCG therapy is associated with interstitial oedema. Many mechanisms were suggested to predispose for this oedema. Ergun et al. (1997) ${ }^{27}$ indicated that testicular blood flow and vascular permeability are increased after hCG treatment. Furthermore, Bergh and Damber $(1993)^{28}$ stated migration of polymorph nuclear lymphocytes in testicular post capillary venules following hCG therapy influencing an inflammation-like reaction and testicular edema. Such inflammation-like morphological changes have also been shown by Hjertkvist et al. $(1993)^{25}$ in biopsies obtained at surgery performed at the end of unsuccessful hCG treatment of boys with cryptorchidism. More recently, Alfonso et al. $(2013)^{29}$ find that hCG treatment causes an increase of Leydig cells production of vascular endothelial growth Factor (VEGF), a major regulator of blood vessel growth and permeability, with an effect of 50,000 times higher than the histamine, whose action is principally expressed in the local tissue, they stated that this factor plays an important role in this oedema.

The findings of dilated and congested blood vessels within the testis as well as rupture blood capillaries are consistent with many other researchers. Kaleva et al. (1996) $)^{30}$; Dunkel et al. $(1997)^{31}$ have been reported an increase in volume density of testicular blood vessels and occurrence of interstitial bleeding in the testis of hCG treated boys. The vascular effect of hCG on the testis is probably due to increased testicular metabolism and accumulation of vasodilative metabolites ${ }^{29}$. Since a direct action of hCG on the testicular vessels seems unlikely, as this mechanism will require specialized vascular receptors to distinguish this organ from other organs which are unresponsive to hCG.

The thinning of seminiferous tubule basement membrane as well as the reduction in collagenous fiber content of the seminiferous tubule lamina propria and the interstitial stroma observed in the current work are supported by the findings of Favorito et al. $(2005)^{32}$ who used stereological methods for quantification of the collagen fibers of cryptorchid patients treated with hCG. They showed that the testicular interstitium and the lamina propria of the seminiferous tubules of patients treated with hCG contained less collagen fibers 
when compared with the testes of non treated patients, and they stated that this reduction is almost temporary. Our findings support this declaration; at the end of the third month post therapy, the density of the collagen fibers of the tubular lamina propria and the interstitial stroma was essentially similar to that of the controls.

It is well accepted that testosterone plays an important role in regulation of the testicular collagen fiber concentrations. The decline in testosterone level with aging has been found to be associated with an augmentation in the volume of collagen fibers in the intercellular matrix of the testis $^{33}$. In contrast, the elevated serum testosterone level manifested at the early stages of this study appears to have a crucial role in reduction of testicular collagen fiber content of the treated rats. This explanation is supported by the fact that the improvement of the collagen fiber content was parallel to the recovery of the serum testosterone levels.

As regards to Leydig cells, the average number of these cells was counted per interstitial space according to Nabil et al. $(2005)^{34}$. The observations of this study are in agreement with those of Scott et al. (1990) ${ }^{35}$ who pointed out that long term treatment of prepubertal or adult rats with hCG or LH results in hyperplasia and hypertrophy of their Leydig cells. Similarly, Kent and Kenneth (1980) ${ }^{36}$ stated that Leydig cell clusters in adult testes enlarge considerably under treatment with excess of hCG or LH. Bergh (1987) ${ }^{37}$ noticed an increase in the volume density of Leydig cells in cryptorchid adult rat after a single injection of hCG.

It has been suggested that in response to hCG stimulation, hypertrophy precedes hyperplasia of
Leydig cells. Lamano et al. (1987) affirmed that hypertrophy plays a more important role in the enhancement of Leydig cells secretory activity in the initial phase of hCG stimulation, while the subsequent hyperplasia seems to become relatively more important in longer periods of treatment. This hyperplasia occurred either due to the over-stimulation of Leydig cells by the hCG, since its signaling plays a major role in Leydig cell proliferation as confirmed by Susana et al. $(2003)^{39}$, or possibly because of maturation of Leydig cell precursors (fibroblast-like cells) in the testis interstitium. Lejeune et al. $(1998)^{40}$ stated that hCG has the ability to stimulate the differentiation of these precursors into their adult type.

Our data suggested that cessation of further stimulation of Leydig cells after withdrawal of the drug caused gradual reduction in the number of these cells, as the excess of Leydig cells was possibly removed by apoptosis (programmed cell death), and each cell was returned back to its normal size due to the restoration of normal tropic hormonal stimulation.

\section{Conclusions}

Administration of hCG affected the seminiferous tubules and the interstitium of the testis. Only the low dose stimulated the spermatogenesis, whereas higher doses suppressed sperm production. Repeated doses of hCG caused hyperplasia and hypertrophy of Leydig cells, interstitial oedema and bleeding. hCG therapy caused reduction in the collagen fibers of the testis, but not affected the general distribution of the PAS +ve material. All these changes are reversible within 3 months. 


\section{References}

1. Anne Cailleux-Bounacer, Yves Reznik, Bruno Cauliez, et al. Evaluation of endocrine testing of Leydig cell function using extractive and recombinant human chorionic gonadotropin and different doses of recombinant human LH in normal men. European Journal of Endocrinology 2008; 159: 171-78.

2. Mazhar Mushtaq, Saghir Ahmed, Abdus Salam, et al. Human Chorionic Gonadotropin (hCG): A treatment of oligospermia. Pak J Med Sci 2007; 23(6): 840-6.

3. Mohamed F Mitwally, Sonya AbdelRazeq and Robert F Casper. Human chorionic gonadotropin administration is associated with high pregnancy rates during ovarian stimulation and timed intercourse or intrauterine insemination.

Reproductive Biology and Endocrinology 2004; 2:55.

4. Goodbar NH, Foushee JA, Eagerton $\mathrm{DH}$, et al. Effect of the human chorionic gonadotropin diet on patient outcomes. Annals of Pharmacotherapy 2013; 47(5): 23.

5. William $\mathrm{H}$ Walker and Jing Cheng. FSH and testosterone signaling in Sertoli cells. Reproduction 2005; 130: 15-28.

6. Saleela M Ruwanpura, Robert I McLachlan and Sarah J. Meachem hormonal regulation of male germ cell development. Journal of Endocrinology 2010; 205: 117-31.

7. Vaskivuo TE, Aittomaki K, Anttonen $\mathrm{M}$, et al. Effects of folliclestimulating hormone (FSH) and human chorionic gonadotropin in individuals with an inactivating mutation of the FSH receptor. Fertil Steril 2002; 78(1):108-13.

8. Zitzmann M, Behre HM and Kliesch S. Gonadotropin treatment in male Infertility. Journal Reproduktionsmed Endokrinol 2013; 10 (1): 23-8.

9. Cathryn A Hogarth and Michael D Griswold The key role of vitamin A in spermatogenesis. $\mathrm{J} \quad \mathrm{Clin}$ Invest 2010; 120(4): 956-62.

10. Takashi O, Hideyuki M, Chiemi M, et al. Follicle-Stimulating Hormone induces spermatogenesis mediated by androgen production in Japanese Eel. Biology of Reproduction 2007; 77(6): 970-7.

11. Dama Madhukar and Singh Rajender. Hormonal treatment of male infertility: promises and pitfalls. Journal of Andrology 2009; 30(2): 95-112.

12. Da-Nian QIN and Mary A Lung. Studies on relationship between testicular capsule and sperm transport in rat testis. Asian Journal of Andrology 2000; 2: 191-98.

13. Slowikowska-Hilczer J and Kula K Comparison between the influence of estradiol benzoate, testosterone propionate and human chorionic gonadotropin on initiation of spermatogenesis in the rat. Ginekol Pol 1994; 65(2):53-7.

14. Kitanaka C, Matsutani M, Sora S, et al. Precocious puberty in a girl with an hCG-secreting suprasellar immature teratoma: Case report. J Neurosura 1994; 81(4): 601-4.

15. Ihsan M Karaman, Cevdet Kaya, Metin Ozturk, et al. The effects of human chorionic gonadotrophin on normal testicular tissue of rats: dose-dependence and reversibility. 
BJU International 2006; 97(5): 1116-8.

16. Kaya C, Karaman MI, Pirincci N, et al. Human chorionic gonadotropin deteriorates the histology of rat Testes. Urol Int 2006; 76: 274-7.

17. Meachem SJ, Schlatt S, Ruwanpura $\mathrm{SM}$, et al. PG The effect of testosterone, dihydrotestosterone and estradiol on the re-initiation of spermatogenesis in the adult photoinhibited Djungarian hamster. Journal of Endocrinology 2007; 192: 553-61.

18. Sofikitis N, Pappas E, Kawatani A, et al. Efforts to create an artificial testis: culture systems of male germ cells under biochemical conditions resembling the seminiferous tubular biochemical environment. Human Reproduction Update 2005; 11(3): 229-59.

19. Charles MA, Alvaro G, Jenny S, et al. Complete Sertoli cell proliferation induced by $\mathrm{FSH}$ independently of $\mathrm{LH}$ activity: evidence from genetic models of isolated FSH action. Endocrinology 2003; 145(4):1587-93.

20. Sarah JM, Saleela MR, Jessica Z, et $a l$. Developmentally distinct in vivo effects of FSH on proliferation and apoptosis during testis maturation. Journal of Endocrinology 2005; 186: 429-46.

21. William H Walker and Jing Cheng Non-classical actions of testosterone and spermatogenesis. Philosophical Transactions of Royal Society Biological sciences 2010; 365: 1557-69.

22. Lynda LL, Dianne" MC, Robert EC, et al. Recommended approaches for the evaluation of testicular and epididymal toxicity. Toxicologic Pathology 2002; 30(4): 507-20.

23. O'Donnell L, Stanton PG, Bartles JR, et al. Sertoli cell ectoplasmic specializations in the seminiferous epithelium of the testosterone suppressed adult rat. Biol Reprod 2000; 63: 99-108.

24. Kerr JB and Sharpe RM. Focal disruption of spermatogenesis in the testis of adult rats after a single administration of human chorionic gonadotrophin. Cell Tissue Res 1989; 257(1):163-9.

25. Hjertkvist M, Lackgren G, Ploen L, et al. Does HCG treatment induce inflammation-like changes in undescended testes in boys. Journal of Pediatric Surgery 1993; 28(2): 254-8.

26. Stina HR, Pernilla W, Andreas J, Ola $\mathrm{C}$ et al. Hormonal regulation and functional role of vascular endothelial growth factor A in the rat testis. Biology of Reproduction 2004; 70: 340-7.

27. Ergun S, Kilic N, Fiedler W et al. Vascular endothelial growth factor and its receptors in normal human testicular tissue. Molecular and Cellular Endocrinology 1997; 131: 9-20.

28. Bergh A and Damber JE. Molecular Biology of the Male Reproductive System. Academic Press Inc, New York; 1993: 439-68.

29. Alfonso Papparella, Fabiano Nino, Carmine Noviello, et al. Morphologic changes due to human chorionic gonadotropin in the rat testis: Role of vascular endothelial growth factor. Open Journal of Pediatrics 2013; 3(2): 85-91. 
30. Kaleva M, Arsalo A, Louhimo I, et al. Treatment with human chorionic gonadotrophin for cryptorchidism: clinical and histological effects. Int $\mathbf{J}$ Androl 1996; 19(5): 293-8.

31. Dunkel L, Taskinen S, Hovatta O, et al. Germ cell apoptosis after treatment of cryptorchidism with human chorionic gonadotropin is associated with impaired reproductive function in the adult. $\mathbf{J}$ Clin Invest 1997; 100(9): 2341-46.

32. Favorito LA, Hidalgo A Jr, Pazos $\mathrm{HM}$, et al. Stereological and morphometric analysis of collagen and seminiferous tubules in testes of patients with cryptorchidism submitted or not to treatment with human chorionic gonadotrophin. Int Braz J Urol 2005; 31(6): 562-6.

33. Gofur MR, Khan MZ, Karim MR, et al. Histomorphology and histochemistry of testis of indigenous bull of Bangladesh. Bangl J Vet Med 2008; 6(1): 67-74.

34. Nabil AM, Ehsan H, Azza H, et al. Reproductive effects of human interferon-alpha- $2 b$ administration on male albino mice testes. The Egyptian Journal of Hospital Medicine 2005; 19: 67-78.

35. Scott IS, Charlton HM, Cox BS, et al. Effect of LH injections on testicular steroidogenesis, cholesterol side-chain cleavage
P450 mRNA content and Leydig cell morphology in hypogonadal mice. J Endocrinol 1990; 125: 1318.

36. Kent A Christensen and Kenneth $\mathrm{C}$ Peacock Increase in Leydig cell number in testes of adult rats treated chronically with an excess of human chorionic gonadotropin. Biology of Reproduction 1980; 22: 383-91.

37. Bergh A Treatment with hCG increases the size of Leydig cells and testicular macrophages in unilaterally cryptorchid rats. Int $\mathrm{J}$ Androl 1987; 10(6): 765-72.

38. Lamano CTL, Favaretto AL, Silva AA, et al. Leydig cell hypertrophy and hyperplasia in adult rats treated with an excess of human chorionic gonadotrophin (hCG). Gegenbaurs Morphol Jahrb 1987; 133(2): $297-$ 309.

39. Susana B Rulli, Petteri Ahtiainen, Sari Ma Kella, et al. Elevated steroidogenesis, defective reproductive organs, and infertility in transgenic male mice overexpressing human chorionic gonadotropin. Endocrinology 2003; 144(11): 4980-90.

40. Lejeune H, Habert R and Saez JM Origin, proliferation and differentiation of Leydig cells. Journal of Molecular Endocrinology 1998; 20 $1-25$. 